\title{
The Aesthetics and Ethics of Contemporary Female Songstress in Javanese Ensemble
}

\author{
Suyoto \\ Faculty of Performing Art, Indonesia Institute of the Arts Surakarta \\ Ki Hadjar Dewantara, No 19, Kentingan, Jebres, Surakarta
}

\section{The research is financed by Lembaga DIPA LP2P3M Indonesia Institute of the Arts Surakarta 2018 \\ Abstract}

Javanese people had various arts and cultures, including karawitan (Javanese ensemble). Javanese ensemble was one of the traditional arts that was still popular and was maintained until now. Surakarta-style Javanese ensemble had elaborate garap instruments, also had garap vocal that was no less complicated than garap instruments. The so-called vocal was: sindhènan. In this study, sindhèn (songstress) was deliberately chosen as the object of study, because sindhèn still existed and had musical and social strength. This was evident in every performance, both in independent musical performances and as supporter of other performing arts, sindhèn always came with its aesthetics. In the last decade, many young sindhèns had little concern for the sindhènan musical principles. In the end, it caused lack of good qualities of the sindhènan that they did. They justified the fact with, "sing penting payu (what matters was that my service could be sold)". Based on this fact, this study seeked to uncover problems related to sindhèn in klenengan performances, including: 1) Why was sindhèn become an important element in Javanese ensemble?, 2) How did the influence of sindhèn on klenèngan performances? Both problems were revealed using garap theory and aesthetic theory. The accumulation of various analyzes carried out in this study, essentially led to the goal of being able to produce a research finding that was centered on the essence of the problem. This was a qualitative research. Information was collected through literature studies, interviews, and direct observations of sindhèn's performances in Surakarta-style Javanese ensemble shows. This study found that sindhèn needed aesthetics and ethics. Aesthetics included, céngkok, luk, wiled, and gregel. While in this term, ethics was meant as the manners of a sindhèn in Javanese ensemble performances. The way sindhèn acted, greatly influenced the klenenngan performances, because it could give its own satisfaction to those who liked performing arts.

Keywords: Javanese ensemble, sindhèn, aesthetic, ethics

DOI: $10.7176 /$ RHSS/9-2-10

\section{Introduction}

The Javanese people at this time were in fact people who were born after Indonesia's independence. They were shaped by very complex, fast and practical socio-cultural situations. Their understanding of Javanese music had also shifted from the understanding held by generations before the independence era, especially the generation that was still experiencing the kingdom era.

During the reign of the Javanese kingdoms, Javanese musical orientation was more focused on ethical, aesthetic, and togetherness issues which led to enhancing human dignity. Javanese ensemble, was known as 'karawitan'. The term karawitan came from the word 'rawit' which meant complicated, subtle, which basically referred more to the arts belonged to the palace. The aesthetic concept of karawitan originating from the palace was subtle, had a high degree of complexity and detail. The meaning of the complexity was related to the strict rules contained in Javanese ensemble Surakarta-style. Rules in detail were reflected in the structure and form of music, orchestration, techniques and play of instruments. Except for the laras, pathet, rhythm, laya, order of performance, instrument layout, even the way to sit when playing instruments, until the way to dress. This rule had been entrenched among Javanese ensemble artists, especially the Surakarta-style, which was then used as a measure of the success of a musical performance.

Javanese ensemble was an art of sound that was generated from Javanese traditional music and human voice in laras sléndro or pélog which prioritized the subtlety of taste (Martopangrawit, 1975: 1). The meaning of karawitan as such had pointed to the characteristics of Javanese ensemble, namely: the medium, the area of culture, the means of expression used, and the scales contained in it. The medium was reflected in the sound expression, indicating that the main ingredient processed in Javanese ensemble was sound. Area of culture was reflected in the Javanese word which showed that Javanese ensemble was interpreted in the context of Javanese culture. Gamelan and human voice pointed to the means of musical expression using gamelan and human voice, while the words sléndro and pélog pointed to the laras used.

After the term Javanese ensemble was used in referring to gamelan music that had laras sléndro and pélog as the styles, it was often combined with the word art in front of it into Javanese ensemble art. The term art had a special meaning of aesthetic expressions that were not found in Javanese culture. All matters relating to musical aspects were further grouped separately as Javanese ensemble art, while gamelan referred to physical forms 
(Hastanto, 1997: 28-53). Thus, Javanese ensemble was a sound art that included instruments and vocals, with the express means of gamelan laras sléndro and pélog that lived and progressed in the context of Javanese culture. Javanese ensemble performances could not be separated from Javanese music (gendhing) repertoire. Therefore sindhèn needed to master many repertoires of Javanese musics, mastering the rules of the sindhènan presented in the show. This meant not just having the courage to present (ora waton wani). In accordance with the times, in fact, there was a habit in Sragen region that was currently developing: "what matters was that my service could be sold (sing penting payu)". It turned out that the progress of the times was very influential on people's lives. This was in accordance with what was revealed by Sedyawati, that the order of life of the community and its changes would affect the development of the arts (Sedyowati, 1991: vii).

Almost all people living in Sragen Regency who wanted to hold a celebration would entertain guests in the form of Javanese ensemble performances (nanggap karawitan). People called it 'nggantung gong'. The large number of requests had led to the proliferation of Javanese ensemble groups that were ready to offer services (to become performers) in the region. Therefore, competition between Javanese ensemble groups was becoming increasingly tight. Each group carried out various strategies, including; 1) used the services of the lurah yaga That was when leader of a Javanese ensemble group appointed one of the trustees who could be trusted to find and coordinate pengrawit, 2) organized, designed, and packaged the variety of compositions that would be presented at each show, 3) No less important was to invite young sindhèns at each performance, even though they did not master the Surakarta-style sindhènan musical rules. This kind of thing had been entrenched in the Sragen Regency, and had even spread to other regions.

Javanese ensemble performances in Sragen Regency area were currently very different compared to the past (in the 70s) which still cared about the finess of taste. At this time, the show only emphasized liveliness, vibrance, and enjoyment. The concept of lively, vibrant, and enjoyable, was not produced by the complexity of the klenengan composition, which was 'ngremit/precise' according to the ideal musical rules. The concept was achieved because of compositions that tended to be harsh musical arrangements, such as dangdut music compositions. Thus the sindhèn who was an expert in the composition of traditional music was not needed, but rather by presenting pesindhèn who could sing pop songs. Things like this were currently taking place in Sragen Regency. Sindhèn with this qualification was commonly referred to by the Sragen people as 'woyo-woyo sindhèn'.

In fact, the Javanese ensemble groups that presented woyo-woyo sindhèn were considered better than the Javanese ensemble groups which only presented the traditional style sindhèn. The reason was the performance of Javanese ensemble groups that presented woyo-woyo sindhèn, was always lively, vibrant, and enjoyable, so the groups got more performances. Local community did not seem to overestimate the existence of traditional experts. For local community, the most important thing was that the sindhè was young, beautiful, could fulfill audience's request to have a dialogue with sindhèn.

This was a very interesting case to study, because this was a new phenomenon in the realm of Surakarta style Javanese ensemble, especially in Sragen Regency. Woyo-woyo sindhèn got a lot of attention in Sragen. The attraction of sindhèn woyo-woyo had even penetrated in other districts. The rise of attention to sindhèn woyowoyo was very influential on art enthusiasts in general. This made the younger sindhèns reluctant to learn sindhènan in accordance with the musical principles of the proper traditional music tradition.

\section{Method}

This research took place in Sragen Regency, precisely in the distribution area of Javanese ensemble performances. The type of research used was qualitative research, meanwhile the data collecting process was flexible, open, dynamic, and easily adapted to any situation, in order to obtain as much data as possible. Data collecting in this research was carried out through stages, namely: the stages of data collection, the reduction and data analysis phase. Data used as conclusion material was a detailed description of the results of data collection obtained from literature studies, observations, and interviews.

Literature studies were conducted to find primary and secondary data containing information needed in this study. Literature studies took precedence on a number of notes, published books, journals, research reports, theses, and dissertations that contained information on matters relating to vocals in Javanese ensemble especially sindhènan. Literature studies conducted in various libraries included: Library of the Indonesian Art Institute (ISI) Surakarta, Pura Mangkunegaran Library, and Radya Pustaka Library of Surakarta. In addition, Researcher also examined a number of encyclopedias and dictionaries related to the term woyo-woyo. Written data related to the sindhènan song were tracked through the notations and its cakepan.

The literature study turned out to be insufficient to explore various informations, so that data collection was also carried out by direct observation. Important events and statements were recorded and the results were verbally described. Direct observation of woyo-woyo sindhènan was very important, in this way researcher could describe the events, so that the data presented was authentic.

Direct observations were made on various Javanese ensemble groups performing in Sragen Regency, 
namely, among others, 1) The Cindhé Laras Javanese Ensemble Group, Jambangan, Sidoharjo, Sragen, which held a performance on August 11, 2018, in Dalangan, Masaran, Sragen, by presenting 3 traditional styles sindhèn and 3 woyo-woyo sindhèns. 2) The Ngudi Laras Javanese Ensemble Group, Banyuning, Singapadu, Sragen. This group held a show on August 12, 2018 in Kembangan, Sidodadi, Sragen, presenting 1 traditional style sindhèn and 1 woyo-woyo sindhèn. 3) The Tardi Laras Javanese Ensemble Group, Sambirejo, Plupuh, Sragen, performed on March 24, 2018, in Celep, Sragen. This group presented 2 traditional style sindhèn, 1 sindhèn woyo-woyo. 4) The Pringgo Laras Javanese Ensemble Group, Pringanom, Sragen. The show was held on April 15, 2018, in Pringanom, Sragen.

In addition to observing the performances, the researchers also made several observations on sindhènan sindhèn shows through audio visual recordings. The reason was: the quality of data recording was more durable than live performance data, and they could be played back, so the research process was easier. The observation material consisted of a number of woyo-woyo sindhènan performances by Wulan, Tumini, Rini, Parmi, and Yuli which had been published through audio-visual recordings.

Interviews were conducted on various occasions to complete the information obtained from literature data and observations. Interviews were were open, profound, and informal. The main interviewees in this study were the sindhèn woyo-woyo, namely: Wulan, Tumini, Rini, Parmi, and Yuli. From the main interviewees, various informations were explored regarding the beginning of sindhèn woyo-woyo becoming popular in Sragen. The results showed that interviewees concluded that Sragen people now preferred performances that were lively, vibrant, and did not like performances that were complex and made in detail.

The interview data with the main interviewees were then compared with the opinions of other informants, namely: Rakinem, Samiyati, Eny, and Suyatmi. Rakinem said that sindhèn, known as woyo-woyo sindhèn, turned out to be sindhèn that did not understand the sindhènan rules, for example, the use of wangsalan and abon-abon. Samiyati, a senior sindhèn, also said the same thing, and woyo-woyo sindhèn could only sing, not nyindhèn.

In addition to interviews with sindhèn, interviews with pengrawit artists were also conducted. The goal, to get information about their views related to sindhèn woyo-woyo. The interviewees included: Agung, Mantili, Donot, Karno, Juwandi, and Sugino. Agung, Mantili, and Donot all had the same view of woyo-woyo sindhèn, the sindhèn which could only sing campursari-style songs.

Interviews were also conducted with users. This was done to find out the reason for users to prefer Javanese ensemble groups that feature young sindhèns. The interviewees who were successfully interviewed were, 1) Purwanto. He was a Sragen resident and had settled in Karangwuni. When he held an event and hired Cindhé Laras Javanese ensemble group, Sidoharjo, Sragen, he said that the presence of woyo-woyo sindhèn could attract public's attention. The sindhèns influenced people's willingness to attend the event (jagong). 2) Hadi Supardi. When holding his son's wedding reception, presented Ngudi Laras Javanese ensemble group from Banyuning, Sragen. He said that Ngudi Laras Javanese ensemble performance was lively, the sindhèns were young. Although the sindhèns that performed were lacked of mastery in traditional Surakarta style musics, it did not become an important issue. Liveliness was important, and the most important was the show could attract as many audiences as it could.

\section{The Life of Surakarta-style Javanese Ensemble}

The journey of Javanese ensemble had gone through various socio-cultural situations, so that its life was coloured by the socio-cultural conditions of its people. Javanese ensemble in the Surakarta style that lived and developed in society had an important role, and was one of Javanese culture expressions in the form of gamelan music. As an important part of culture, art is an expression of the creativity of the culture itself (Kayam, 1981: 38).

Surakarta-style Javanese ensemble was a dynamic performing art. The life was influenced by various kinds of life in the supporting community. The existence of Surakarta-style Javanese ensemble was one of the manifestations of the Javanese life system. Changes in the community's life system would influence the dynamics of Javanese ensemble. The community's life system and its changes would determine the dynamics of the arts (Sedyowati, 1991: vii).

In the 1970s Javanese ensemble developed rapidly in the middle of Javanese community. The rapid growth happened because it gained support from the community. This could be proven, in various events such as weddings, circumcision parties, 'selapanan' (celebrating the first $35^{\text {th }}$ day of a baby's life), and other social needs such as bersih desa, nyadran, after-harvest celebrations and thanksgiving, Agustusan performances (independence day celebration), all still using Javanese ensemble as one of the entertainment. Javanese ensemble was asked to perform in the form of stand-alone music entertainment and as musical support for other performing arts, such as wayang kulit, kethoprak, tayub and so on. This was concrete evidence that the growth of Javanese ensemble could not be separated from its community. That when traditional performing arts experienced its golden age in the late 19th century until the mid-20th century. (Soedarsono, 1999: 6). 
When Javanese people held party with Javanese ensemble as the entertainment, of course they had certain goals, one of which was that guests were willing to attend. For these people, the ability to hold Javanese ensemble performances (nggantung gong) especially when they could nanggap wayang by hire top rank dalang (puppet player), to provide entertainment for the common people, was a matter of pride. Another goal was to get authority, flattery (jw. golèk wah). Nanggap was meant to be an activity using the services of other people, both individuals and groups, by providing compensation in the form of money. Tanggapan, in the show business were activities to use services to get money in return. Starting from the large number of Javanese ensemble service users, then market-oriented Javanese ensembles were emerged.

The emergence of market-oriented Javanese ensemble groups was a manifestation of the commercialization that took place in Javanese traditional music. Javanese community called it as a 'tanggapan'. In Java, this traditional ensemble was an inseparable part of the lives of its people, especially in Solo Raya (Boyolali, Klaten, Sukoharjo, Karanganyar, Wonogiri, Sragen), and Surakarta. In these regions there were still many people who used Javanese ensemble performances, especially in events. People who used Javanese ensemble services were then called 'nanggap'.

\section{The Life of Javanese Ensemble in Sragen}

Based on distribution data of Javanese ensemble groups in Sragen Regency, there were approximately 90 Javanese ensemble groups that were still alive. Most of them were ensemble groups that were still active and got demand for performances in various events in the community. The number of Javanese ensemble groups in Sragen Regency was very influential on the existence of supporting artists. If the commercial Javanese ensemble groups were formatted in klenenngan jangkep, it required tens of pesindhèns, even hundreds of pesindhèns. This showed that Sragen was a suitable area for musical life. $90 \%$ of the existing Javanese ensemble groups were commercial groups that routinely got requests for performances from the public.

\section{Gending (Musical) Repertoire}

Today's Javanese people were they who were born after Indonesia's independence. They had never experienced ritual ceremonies that existed in the past. This people had been shaped by complex, fast-paced, and practical socio-cultural situations. It was ensured that their understanding of Javanese ensemble was less than that of the generation before Indonesia's independence day, moreover than the generation that was still experiencing the kingdom style government system.

During the reign of the kingdom, Javanese ensemble orientation was more heavily charged with ethical, aesthetic, and togetherness elements which led to heightening the level and dignity of humanity. Changes in society's system of life had an influence, including the progress of Javanese ensemble. Edy Sedyowati stated that at the same time the community would contribute to the progress of its art (Sedyowati, 1991: vii).

Javanese ensemble performances could not be separated from gending repertoires, this meant that pengrawits were required to master many gending repertoires presented in the show. Because of the large number of Javanese ensemble groups, competitiveness had become increasingly stringent. Each group carried out various strategies, including; 1) used the services of the lurah yaga That was when the leader of the karawitan group appointed one of the trustees who could be trusted to coordinate pengrawit and to compose the gendings, 2) increased the pengrawit's skills, the abilities in composing and arranging the gendings that would be presented at each show, 3) to invite young sindhèns at each performance, even though they did not master the Surakarta-style sindhènan musical rules in order to attract the community. 
Table 1. Repertoire of gending klenengan for day times

\begin{tabular}{|c|c|c|}
\hline Time & Gending Sequence & Garap \\
\hline $\begin{array}{l}09.30 \\
\text { to } \\
12.00\end{array}$ & $\begin{array}{ll}\text { 1. } & \text { Bonangan } \\
- & \text { Harjuna mangsah, ldr lrs pl pt barang. } \\
- & \text { Tukung, gd kt } 4 \mathrm{kr} \text { mg } 8, \text { lrs pl pt barang. } \\
\text { 2. } & \text { Klenèngan } \\
- & \text { Wilujeng, ldr, lrs pl pt barang. } \\
- & \text { Widosari, gd kt } 2 \mathrm{kr} \text { mg } 4 \text { lrs sl pt manyura. } \\
- & \text { Pathetan sanga wantah } \\
- & \text { Jineman Uler Kambang, sl sanga } \\
- & \text { Gambirsawit, lrs sl pt sanga (mrabot) }\end{array}$ & $\begin{array}{l}\text { - not using sindhèn yet. } \\
\text { - not using sindhèn yet } \\
\text { - traditional style sindhèn } \\
\text { - traditional style sindhèn } \\
\text { - traditional style sindhèn } \\
\text { - traditional style sindhèn } \\
\text { - traditional style sindhèn }\end{array}$ \\
\hline $\begin{array}{ll}13.00 \\
14.15\end{array}$ & $\begin{array}{l}\text { 1. Gending-gending garap tayub, seperti: } \\
\text { - Ktw. Puspawarno, lrs sl pt manyura } \\
\text { - Ktw. Bandhung alus, lrs sl pt manyura } \\
\text { - Lcr. Blandhong, lrs sl pt manyura } \\
\text { - Lcr. Kijing miring, lrs sl pt sanga } \\
\text { 2. Garap langgam } \\
\text { - } \quad \text { langgam Sri Uning, lrs sl pt sanga } \\
\text { - } \\
\text { - } \\
\text { Langgam kelinci ucul, lrs pl pt barang. } \\
\text { - } \\
\text { - } \\
\text { - } \\
\text { Langgam Gagat enjang, ls pl pt nem Dadi ati, lrs pl pt barang } \\
\text { - Langgam Atiku lega, lrs pl pt em } \\
\text { - } \quad \text { Langgam Ajuring ati, lrs pl pt nem } \\
\text { Lagon Runtiking Ati, lrs pl pt nem } \\
\text { Lagon Imbangana Katresnanku } \\
\end{array}$ & $\begin{array}{l}\text { - traditional style sindhèn } \\
\text { - traditional style sindhèn } \\
\text { - traditional style sindhèn } \\
\text { - traditional style sindhèn } \\
\text { - } \\
-\end{array}$ \\
\hline $\begin{array}{l}14.30 \text { to } \\
15.30\end{array}$ & $\begin{array}{ll}1 . & \text { Various campursari songs } \\
- & \text { Lagon jambu alas, lrs pl pt nem } \\
- & \text { Slendhang Sutra kuning, lrs sl pt sanga. } \\
- & \text { Lagon Aja Cidra, lrs sl pt sanga } \\
- & \text { Gubug Asmara, lrs sl pt manyura. } \\
& \\
\text { 2. } & \text { Langgam pamitan, lrs sl pt sanga as a sign that } \\
\text { the performance was complete }\end{array}$ & $\begin{array}{ll}- & \text { sindhèn woyo-woyo } \\
- & \text { sindhèn woyo-woyo } \\
- & \text { sindhèn woyo-woyo } \\
- & \text { sindhèn woyo-woyo } \\
& \text { sindhèn woyo-woyo }\end{array}$ \\
\hline
\end{tabular}

\section{Ethic and Aesthetics of Sindhènan}

In Javanese ensemble, art performers were not only instrument performers, but also involved vocal performers. Vocal in Javanese ensemble included: sindhènan, båwå, gérong, senggakan, and alok. Their presence was to add to the aesthetics of Javanese ensemble. In Surakarta style Javanese ensemble there were several types of vocals whose presentation were grouped into two, namely single vocals and group vocals. Single vocals were vocals that were present independently, namely: sindhènan and båwå. Group vocals were vocals that were presented by more than one person together (choir), namely: gérong, senggakan, and alok.

General understanding circulating in the midst of society so far, sindhèn was a woman who usually presented vocals in karawitan, then in the society it was commonly called pesindhèn, swarawati, waranggana, and seniwati, in certain regions there were those who called lèdhèk. Martopangrawit stated that sindhènan was a female vocal accompanying Javanese ensemble (Marto Pangrawit, 1972: 1). Sindhèn was a verb which meant to sing solo in Javanese ensemble, while sindhènan refered more to material in the form of songs and cakepan. This understanding led to the knowledge that sindhènan was a female single vocal that accompanied Javanese ensemble, both those using wangsalan and those using special cakepan (poetry).

According to the type, sindhènan was divided into two groups, namely: general sindhènan, and special sindhènan. General sindhènan was sindhènan which used wangsalan as the main text, and abon-abon as a supplement, hereinafter referred as sindhènan sranbahan. Special sindhènan was a sindhènan that used cakepan or special songs. Because of its specificity, it could not be used for other compositions. For examples were: sindhènan gawan, sindhènan sekar, jineman, and palaran. 
Diagram 1. Formation of Sindhènan

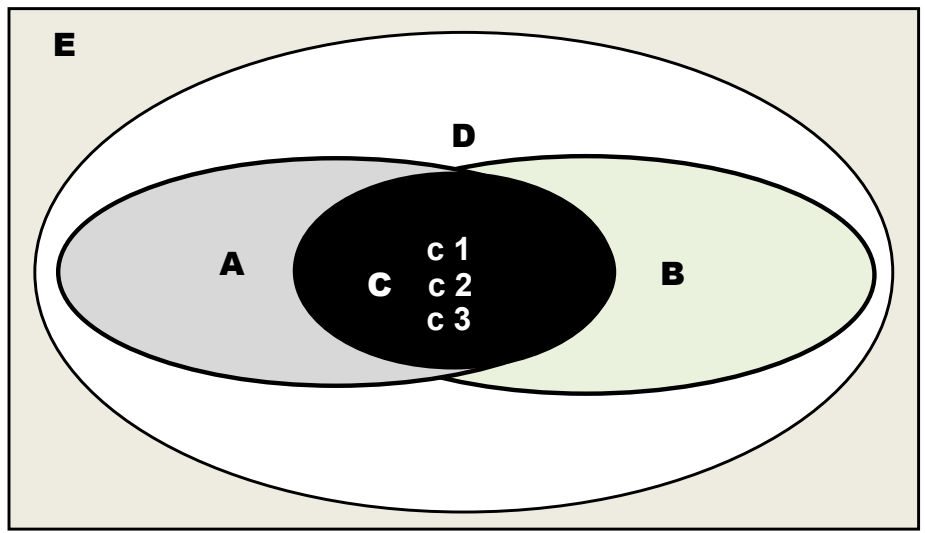

E. Sindhènan
A. Medium (language, note)
B. Vocabular céngkok
C. Garap
$\left\{\begin{array}{l}\text { C.1. garap medium } \\ \text { C.2. garap vocabular } \\ \text { C.3. garap rasa }\end{array}\right.$

\section{Medium}

Wangsalan

Wangsalan was a kind of Javanese traditional poetry which the sentence order was arranged according to predetermined syllables, and in the sentence implied veiled questions and answers. Wangsalan was divided into two parts, the first part was called cangkriman or puzzle, while the second part was the answer to the previous puzzle, which sometimes had nothing to do with the first sentence, but the second part was the core of a wangsalan. In Java there were several types of wangsalan that were used in art and in daily life. The type of wangsalan referred to was as followed.

\section{Wangsalan lamba}

Wangsalan lamba was a type of wangsalan arranged in one sentence and divided into two phrases. The first phrase contained a question, the second phrase contained an answer. There were 3 types of wangsalan lamba, namely: 1) the first phrase consisted of 4 syllables containing questions, the second phrase 4 syllables contained the answer. Example: Kawis pita, wus bejané. Kawis pita was the term for maja fruit, answered in the word bejané by equating the syllable -ja. 2) the first phrase consisted of 8 syllables containing questions, the second phrase 8 syllables contained the answer. Example: Aran ludiraning wreksa (sap), ywa kapatuh ngumbar karsa, was answered in the word kapatuh. 3) the first phrase consisted of 4 syllables containing questions, and the second phrase 8 syllables contained an answer. For example:

1. Menyan seta, tiwas-riwas tanpa karya.

(tawas/alum), was answered in the form tiwas-tiwas.

2. Sekar arèn, sewu bekja kemayangan.

(mayang/flowers stem of palm tree), was answered in the form kemayangan.

3. Kawi sekar, den sugih tepa salira.

(puspa/flower) was answered in the form tepa.

\section{Wangsalan rangkep}

Wangsalan rangkep was wangsalan which was arranged in two parts. The first part consisted of 12 syllables and contained questions, which was divided into two phrases. The first phrase consisted of 4 syllables, and the second phrase consisted of 8 syllables. The second part contained answers, also consisting of 12 syllables divided into two phrases like the first part.

Example:

Part I : Lalu mangsa, panusuling magut yuda;

Part II: Yèn kasèpa, mbantoni lara asmara.

Part I first phrase: lalu mangsa meant kasèp, was answered on the second part of first phrase, which was 'yen kasepa'. Part I second phrase Panusuling magut yuda meant to help in a war, was answered on the second part of second phrase which was mbantoni.

\section{Céngkok vocabulary}

In addition of using cakepan, sindhènan also used song patterns (céngkok). Sindhènan was a song that was presented in the section seleh. Thus it was understood that the pattern of the sindhènan song was céngkokcångkok sèlèh which was expressed through notes. Example: 
The song patterns of sèlèh sindhènan or céngkok sèlèh were those that used wangsalan text in laras pélog pathet barang.

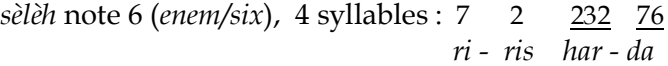

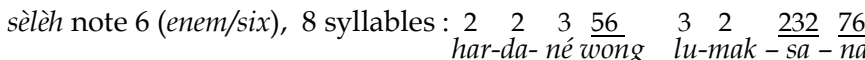

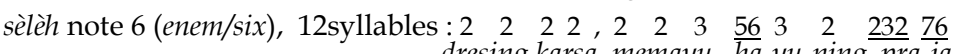

$$
\begin{aligned}
& \text { dresing karsa memayu ha-yu-ning pra-ja }
\end{aligned}
$$

\section{Garap wangsalan}

The meaning of the term garap was a creative work of an artist in which there was imagination and interpretation in understanding and presenting sindhènan. Important elements of sindhènan were wangsalan vocabulary, céngkok, gregel, and wiled. For example: Ladrang Wilujeng, laras pélog pathet barang.

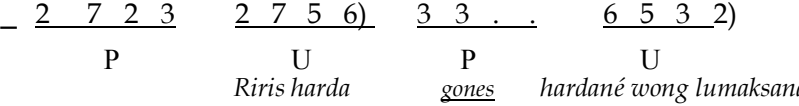

$$
\begin{aligned}
& \frac{5653}{\mathrm{P}} \quad \frac{2756)}{\mathrm{U}} \quad \frac{27 \quad 23}{\mathrm{P}} \quad \frac{275(6)}{\mathrm{U}} \\
& \text { rama-rama dresing karsa, ramanédhewé memayu hayuning praja }
\end{aligned}
$$

$$
\begin{aligned}
& \text { Ngelik: gérong salisir }
\end{aligned}
$$

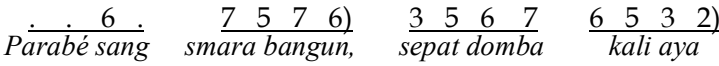

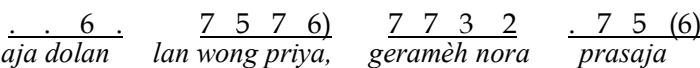

The underlined words were isen-isen, the ones in which the application were located in light seleh part or padhang $(P)$. Wangsalan was located in a heavy seleh or ulihan $(U)$. Ngelik did not use wangsalan, because the gending used gérongan, therefore the sindhènan used cakepan which was used in gérongan.

\section{The Phenomenon of Sindhèn Woyo-Woyo}

In Sragen region there was currently a fairly phenomenal term, namely sindhèn woyo-woyo. Sindhèn woyo-woyo was a sindhèn who cared less about aesthetics and ethics, as well as the Surakarta style sindhènan rules as outlined above. It could be said that sindhèn woyo-woyo was sindhèn which could not present Surakarta-style musical compositions. Sindhèn woyo-woyo was sindhèn which could only present campursari-style songs that were well-known today. The reason was to meet the demands of the market, because the majority of audience prefered lively and enjoyable performances rather than subtle and complicated things.

Actually, the highest aesthetic achievements were needed in the world of Javanese ensemble performance including sindhènan. Therefore, aesthetic achievements needed to get special attention, because there were things that were very crucial and needed to be understood by pesindhèn, such as: the type of sound, laras, dynamics, and cengkok compatibility applied, as offered by Marc Benamou about type of sound, arum, renyah, ulem, etc. (Benamou, 1998: 411). These types of sound classification were used to sort the sound color match in sindhènan with regard to céngkok application, wiled, and gregel which were appropriate for achieving sindhènan at the maximum level. The terms arum, renyah, ulem, and anteb, as well as céngkok application, luk, wiled, and gregel in sindhènan were aesthetic experiences obtained from the experiences of sindhèn maestro. Colin Leath said that all experiences could be called aesthetic experiences (Colin, 1996: 1).

In fact, the Javanese ensemble performances in Sragen region were more concerned with quantity than maintaining quality. This was evident in Javanese ensemble performances, there were two groups of sindhèn, namely on-stage sindhèn and off-stage sindhèn. 


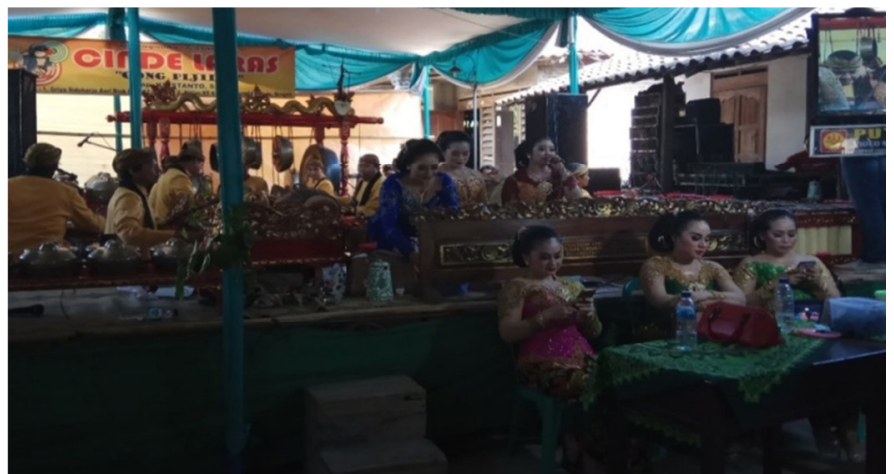

Picture 1. Day time Javanese ensemble "Cindhe Laras" (photo: Suyoto, 2018)

Such conditions were now occuring Sragen region and its surroundings. Sindhèn which was off-stage was sindhèn woyo-woyo, which currently attracted the attention of event organizers and Javanese ensemble show enthusiasts. For event organizers, the presence of the sindhèn woyo-woyo felt beneficial, because more guests would come, so that it would financially increase their income. The audience would be happier, because they could freely dialogue, ngibing (dancing), sing together, so the atmosphere would be more lively and enjoyable.

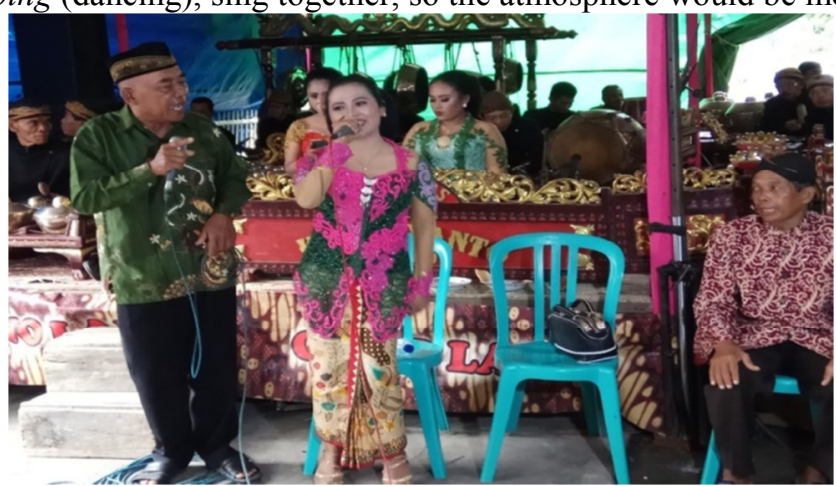

Picture 2. Audience was singing together with a sindhèn woyo-woyo (photo: Suyoto, 2018)

\section{Conclusion}

In Sragen Regency, there was the term 'nggantung gong', meaning that almost every citizen who organized a party always involved Javanese ensemble (nanggap karawitan). That was the reason that made people refered to these activities with the term 'nggantung gong'. Nggantung gong at each party was not impossible, because in Sragen Regency there were many Javanese ensemble groups that were ready to accept show requests (tanggapan). No less important, was to fulfill the demand for presenting young pesindhèn, although they did not master the Surakarta-style sindhènan rules, which then made them called the sindhèn woyo-woyo.

Sindhèn woyo-woyo still existed and had a strong influence in the community. This was evident in every performance, both in stand-alone Javanese ensemble shows (klenengan) and when Javanese ensemble was being performed to support other performances (wayang kulit), sindhèn woyo-woyo was always present. In the last decade, young pesindhèn had little concern for musical principles as garap vocal, ultimately the quality of the sindhènan was not optimal.

Sindhèn woyo-woyo were popular, because they were usually young, beautiful, sociable and friendly. Personality like this was in accordance with the tastes of today's society, which basically liked a lively and enjoyable performances.

Sindhèn woyo-woyo had strong influences on show audience. This was because the show became enjoyable and intimate, so party organizers were more interested than the shows without sindhèn woyo-woyo. Familiar and enjoyable performances could give satisfaction to the audience, as well as art users.

\section{References}

Benamou, Marc. "Rasa in Javanese Musical Aesthethics". Disertasi Doktoral (Musikologi). Michigan: University of Michigan, 1998.

Darsono. "Perkembangan Musikal Macapat". Surakarta: Laporan Penelitian S.T.S.I. Surakarta, 1994.

Hastanto, Sri. Konsep Pathet Dalam Karawitan Jawa. Surakarta: Program Pasca Sarjana bekerja sama dengan ISI Press, 2009. "Gendhing: Parameter Keseimbangan Hidup", Pidato Dies Natalis ASKI Surakarta XXII. Surakarta: ASKI Surakarta, 1986. 
Kurniatun, Isti. “ Sindhènan Ayak-ayak Céngkok Sri Supadmi”, Surakarta: Laporan Penelitian STSI Surakarta, 1995).

Santoso. Komunikasi Seni: Aplikasi Dalam Seni Pertunjukan Gamelan. Surakarta: ISI Press, 2011.

Supanggah, Rahayu. Bothèkan Karawitan II: Garap. Jakarta: The Ford Foundation \& Masyarakat Sèni Pertunjukan Indonesia, 2007.

Suparno, T. S. "Sindhènan Andhegan Nyi Bei Mardusari." Surakarta: Laporan Penelitian, 1984/1985.

Suraji. "Sindhènan Gaya Surakarta” Surakarta: Tesis Sekolah Pascasarjana ISI, 2005.

Suyoto. "Sindhènan Gendhing Sekar Versi Sastra Tugiya". Surakarta: Laporan Penelitian S.T.S.I Surakarta, 1995.

, Carem: Puncak Kualitas Bawa Dalam Karawitan Gaya Surakarta. Yogyakarta: Disertasi Sekolah Pascasarjana Universitas Gadjah Mada Yogyakarta, 2016.

\section{Interviewees}

Agung (45), a pengrawit, rebab (Javanese-style fiddle) instruments specialist, Banyuning, Sidoharjo, Sragen.

Eni (42), Senior pesindhèn, Surakarta-style Javanese ensemble, Sekarpace, Surakarta

Gino Saputra, (32) A pengrawit, kendhang (two-headed drums) instruments specialist, Cungul, Celep, Sragen

Hadi Supardi (63), A member of society, Javanese ensemble group user, Kembangan, Sidodadi, Sragen

Intan, (25), Sindhèn woyo-woyo, Kerjo, Sragen

Karno (50, Pengrawit, a vocalist and a rebab specialist, Mloko Legi, Sragen

Mantili (46), pengrawit, demung (a melody provider instrument in Javanese ensemble) specialist, Ngunut, Sidoarjo, Sragen

Purwanto (44), a member of society, Javanese ensemble group user, Dalangan, Kliwonan, Masaran, Sragen

Rini (30), sindhèn woyo-woyo, Mojosongo, Surakarta

Rakinem (57), senior pesindhèn in Surakarta-style Javanese ensemble, Sapen, Sragen

Samiyati (58), senior pesindhèn in Surakarta-style javanese ensemble, Sukorejo, Sragen

Suparlan, (57),. a pengrawit and a Javanese-style master of ceremony, Dalangan, Kliwonan, Masaran, Sragen

Tumini (40), a sindhèn woyo-woyo, Jatikuwung, Gondangrejo

Yuli (39), a sindhèn woyo-woyo, Sidoharjo, Sragen 